\title{
IMPACT ANALYSIS OF MADRASAH CLIMATE ON ITS PRODUCTIVITY IN WEST BANDUNG REGENCY
}

\author{
Eliza Metiasari Putri ${ }^{\text {a* }}$ \\ a*Madrasah Aliyah Muslimin Cijenuk \\ Citalem, Cipongkor, Kabupaten Bandung Barat, Indonesia Elizaputri89@ rocketmail.com
}

\begin{abstract}
The background of this study focuses on the influence of madrasah aliyah climate on its productivity in West Bandung regency. The purpose of the study is to illustrate: 1) madrasah climate in West Bandung regency 2) the influence of Madrasah Climate on the productivity of madrasah aliyah in West Bandung regency. The research method is using descriptive method with questionnaire collecting technique toward 187 certified teachers spread in madrasah that have accreditation A and B. The description of research result indicates that Madrasah Climate is in good category or quite high and the madrasah climate has a positive effect on its productivity.
\end{abstract}

Keywords: Impact Analysis, Madrasah Climate, Madrasah Productivity.

\section{INTRODUCTION}

School productivity is a form of educational productivity on a smaller scale. Madrasah is one of the determinants of the quality of human resources. Through this institution learners both mentally and intellectually trained, the school as an educational organization becomes a place of teaching and learning process to achieve national development, this success depends on the human resources that exist in the school.

According to Superintendent Madrasah Aliyah West Bandung regency, Madrasah Aliyah has no strategic plan in accordance with the real situation and condition because in the making a lot of copy and paste. The misbehavior of the Aliyah pupils is getting bigger and challenging as well as the level of continuing to college is still very low.

Recorded in research that the low quality of madrasah education due to several factors including: (1) Performance MA chief who does not have a clear vision and mission; (2) the culture of MA organization that is not conducive is the existence of dualism in management between head of Madrasah and chair of foundation (3) teacher competence not yet optimal. Besides, it is caused by (1) limited facilities and infrastructure; (2) the attractiveness of the program is still low; (3) lack of adequate human resources; And (4) the curriculum that has not answered the need, that is still concerned with the material above the methodology, prioritizing the above analysis and still be traditional or not touch the rational aspect.

In addition to performance headmaster climate madrasah also greatly affect the productivity, to get a good climate it is necessary to harmonious relations between all citizens of madrasas environment and work climate that will encourage employees to be happy to work and create enabling conditions and circumstances conducive to increasing productivity so Become a productive madrasah. 


\section{METHODS}

said that research method is defined as a scientific way to get data with a specific purpose and usefulness. The method used in this research is explanatory survey method or explanation is a method that highlights the relationship between variables using the frame of thought and then formulated a hypothesis. While the approach used in this study using a quantitative approach. The analytical technique used is the regression analysis of this technique of analysis is used to give the proportion or percentage of total variation in the independent variable $\mathrm{Y}$ described by the independent variable $\mathrm{X}$.

The data collection techniques performed to obtain the data as follows: Study documentation, which is a study to find data about things in the form of notes, reports, and documents. The study of literature is the study or technique of collecting data by obtaining or collecting data from books, reports, magazines, and other print media related to the issues studied. Questionnaire, the data collection is done through the use of a list of questions that have been prepared and distributed to the respondents in order to obtain the required data. The statement in the Questionnaire was prepared with an alternative answer to the Fivepoint Likert Scale. Questionnaires were developed based on indicators of each research variable. Each of the 5 available answer answers is assigned a weighted value. The steps of preparing the questionnaire are: a) preparation stage: among others First, arranging the instrument grid derived from the variable to the indicator which then formulated the instrument grille that will be poured in some research questions, second spread the questionnaire to the students Sampled in this study, Third process and analyze data which then presented in the form of research report.

The sample in this research is the teacher is certified in A and B accreditation school with the total number of 187 people.

\section{RESULTS AND DISCUSSION}
A. School Climate Description of Madrasah Aliyah in West Bandung regency

In general, madrasah climate in madrasah aliyah neighborhood in West Bandung has been good, it can be seen from the three climate dimensions that become the measurement material has good average value, that is the climate of organizational openness, organizational health climate and citizenship climate. Of the three dimensions, the organizational openness climate has the highest average value of 3.54 is in very good criteria; while the lowest is the climate of citizenship/community with an average value of 3.18 is in good criteria. Open climate is characterized by cooperation and respect among teachers and leaders. The cooperation creates a climate in which the leader listens and is open to the teacher, the leader gives a truly sincere, continuous, and respectful gift to the professionalism of the teacher (high support) and gives the teacher the freedom to act. The teacher's behavior is supportive, open, and relationship with peers. Teacher shows open friendship (high intimacy), and commitment to work. Based on the results of data processing on this dimension obtained high results. It is motivated that the head of the madrasa is open to input from the teacher. All madrasah support each other in mutual progress. One of the underlying characteristics of madrasah is that society comes from society and for society. Thus, this high sense of belonging to madrasah.

Climate Citizenship is another dimension of citizenship/society. The climate of citizenship is where teachers generally behave in a useful way. They are usually concerned with the interests of others, be cautious, be sporty, show respect, and behave well. In this dimension with the indicator of altruism is the importance of other people get a low score.

B. The Influence of Madrasah Climate on Madrasah Productivity

The result of the research shows that there is a significant and positive influence between Climate variables of each score change on Climate School variable of one unit, then there will be a change in the Productive Teacher Performance score of 0.884 . That is, any change (increase or decrease) of one unit in madrasah climate, it will also affect the managerial performance of madrasah head of 
0.884 units. This suggests that madrasah climate has an effect on productivity, with a positive change direction. It shows that the rise and fall of madrasah productivity (dependent) can be done through increasing or decreasing madrasah climate. Because it is a positive sign, the change is either development or improvement.

Another study conducted showed that the effect of organizational climate on school productivity in Cirebon City has a correlation coefficient value of 0.758 is at a strong level. The value of determination produced is $57.4 \%$ meaning that school productivity is influenced by organizational climate of $57.4 \%$ and the remaining $42.6 \%$ is influenced by other factors. This shows that a conducive climate will produce a productive performance. And productive performance will produce good organizational quality. concludes that the school climate is vital to its existence that ensures personal growth within it, which is a pleasure to be part of school personnel, the passion to provide the best learning service, and to be free from work anxiety. This is also supported by the opinion of which states that good environmental and organizational climate will encourage teachers to enjoy work and increase their sense of responsibility to do a better job towards productivity.

A positive school organizational climate will make all madrasahs involved become individuals who focus on madrasah goals and further to advance education. A healthy school climate will provide comfort in working for all components. The open climate is reflected in the good relationships of teachers, teachers and heads of madrasas, how the headmaster positions in giving encouragement, and is open in relation to teachers. The behavior of teachers in schools takes place openly, even leads to the involvement of feelings between fellow teachers that impact on mutual respect and feel what is felt by other teachers and the head of the madrasah. describes a conducive climate with good relationships, listening and open to critique and suggestions, giving praise, and conducting cosmological criticism, open and professional interactions in the sense of pride of teachers to the school, the pleasure of working with colleagues. Mutual acceptance and appreciation of their respective competencies. The importance of organizational Climate in creating productivity hence should head of madrasah have to create and keep madrasah climate to always be conducive because it is a manifestation of effectiveness as a leader in managing and utilizing the citizens of the school. As can be seen in the following figure:

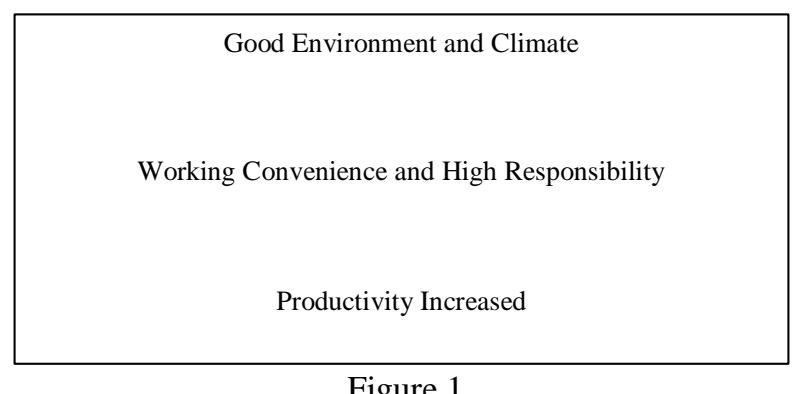

Figure 1

\section{CONCLUSION/RECOMENDATION}

The results showed that madrasah climate contributed positively to madrasah productivity. A conducive madrasah climate will encourage an increase in the productivity of madrasah.

In an effort to improve madrasah productivity some of the recommendations proposed are;

1. The head of a madrasah should create a conducive climate for all madrasah citizens by providing equal opportunity and treatment to all school residents, involving more teachers in any event. The existence of regulation in the Ministry of Religious Affairs at the regency/municipality level in regulating the requirements for the appointment of the head of the madrasah is strongly required, so there would be a coherence between the qualifications and competence in the field.

2. Creating a conducive climate by fostering openness and two-way communication between the head of madrasah, teachers, committees and administrators of the foundation by way of internal coaching that can be done by the foundation. 


\section{December 2017}

\section{REFERENCES}

Dipaola, Michael. \& Moran, MT. 2014. Organizational Citizenship Behavior in schools and Its Relationship to School Climate in Journal of School Leadership Vol 11 No. 5 pp. $424-462$

E. Mulyasa, (2007), Menjadi Guru Profesional, Bandung : PT Remaja Rosdakarya.

E. Mulyasa, (2009), Menjadi Kepala Sekolah Profesional, Bandung: PT Remaja Rosdakarya.

Kasempap, Kijpokin. 2016. Unifying a Framework of Organizational Culture, Organizational Climate, Knowledge Management, and Job Performance in Entrepreunership: Concepts, Metthodologies, Tools and Applications Journal pp. 270 - 298

Komariah, Aan (2014), kepemimpina transformasional,iklim sekolah, kinerja mengajar guru dan produktivitas sekolah. Jurnal administrasi Pendidikan.

Komariah, Aan., Engkoswara. 2010. Administrasi Pendidikan. Bandung:Alfabeta

Nasution, AP., Mahargiona, PB., \& Soesatyo, Yoyok. 2016. Effect of Leadership Styles, Organizational Climate and Ethos of Work on Employee Productivity (PT. HP Metals Indonesia the Power Coating). In International Journal of Business and Management Vol. 11 No. 2 pp. 262 - 273

Novianto, Eka, (2016). Pengaruh Kepemimpinan Visioner Kepala Sekolah dan Iklim Sekolah
Terhdapa Produktivitas Sekolah. Vol VII No 3a Jan 2016: 16

Saparudin, Yudhi. (2012). Pengembangan Produktivitas Madrasah. Jurnal Administrasi Pendidikan. Vol XIII No 2 2012: 2

Sedarmayanti, (2009), Sumber Daya Manusia dan Produktivitas Kerja, Bandung: CV Mandar Maju. Shahmoradi, Morad., Rezaee, Zahra., Sheikhi, Saeed., \& Darabian, Sajad. 2016. The Relationship between Organizational Climate, Organizational Culture and Creativity with Job satisfaction of Librarians in Ahwaz Public Libraries in Research Journal of Psychology and Educational Sciences Vol. 2 (4) pp. $94-101$

Sugiyono, (2001), Metode Penelitian Administrasi, Bandung: Alfabeta.

Thapa, Amrit., Cohen, Jonathan., D’Alessandro, Ann Higgins 7 Guffey, Shawn. 2012. School Climate Research Summary: August 2012. National School Climate Center [Online] downloaded from

https://www.schoolclimate.org/climate/documen ts/policy/sc-brief-v3.pdf 